\title{
A acumulação primitiva continuada
}

\author{
Eric Alliez; Maurizio Lazzarato
}

(Tradução do segundo capítulo (L'accumulation primitive continuée) de Guerres et Capital. Paris: Éditions Amsterdam, 2016.

Traduzido por Carolina Sarzeda e Danichi Hausen Mizoguchi.)

DOI: $10.12957 /$ mnemosine.2020.57670

\section{2/ A acumulação primitiva continuada}

\begin{abstract}
Os diferentes métodos de acumulação primitiva que a era capitalista faz eclodir repartem-se, a princípio, por ordem mais ou menos cronológica, Portugal, Espanha, França e Inglaterra. Até aquele método que, no último terço do século XVII, combina em si mesmo todos os outros em um conjunto sistemático, imbricando ao mesmo tempo o regime colonial, o crédito público, o financiamento moderno e o sistema protecionista. Alguns destes métodos repousam sobre o emprego da força brutal, mas todos, sem exceção, exploram o poder do Estado, a força concentrada e organizada da sociedade, a fim de precipitar violentamente a passagem da ordem econômica feudal à ordem econômica capitalista e de abranger as fases de transição. E, efetivamente, a Força é a parteira de toda velha sociedade em trabalho de parto. A Força é um agente econômico.
\end{abstract}

Karl Marx Le Capital, livre I, section VIII [Karl Marx, O Capital: Crítica da economia política. livro I, seção VII, cap. XXIV. $2^{a}$ ed. São Paulo: Boitempo 2017, p. 821. N.T.]. [48]

Na seção d'O Capital consagrada à acumulação primitiva, Marx descreve perfeitamente as duas potências de desterritorialização que engendraram o capitalismo: por um lado, as guerras de conquista, a violência das invasões e das apropriações das terras "virgens" do novo Mundo; por outro, o crédito, a dívida pública (“o crédito público, eis o credo do Capital ${ }^{1 “}$.), sustentados, levados a cabo, organizados pelos Estados europeus. Para Marx, estas não constituem senão as pré-condições do capital, destinadas a serem superadas e reconfiguradas pelo "capital industrial" no desenvolvimento das forças produtivas que fornecer, a seu turno, a base material progressista da tecnologia da revolução. A esta dialética na qual se baseia a ideia de que haveria uma via "verdadeiramente revolucionária" na transição (nacional) para o capitalismo, que é esta ideia da "revolução" burguesa, nós contrapomos esta primeira evidência

\footnotetext{
${ }^{1}$ Karl Marx, Le Capital, livre I, section VIII, chap. XXXI, in Euvres, t. I, Paris, Gallimard, "Bibliothèque de la Pléiade", 1962 p. 1217. E em conseguinte: "também a ausência de fé na dívida pública vem, desde a incubação desta, tomar o lugar do pecado contra o Espírito Santo, outrora o único imperdoável". [Karl Marx, O Capital: Crítica da economia política. livro I, seção VII, cap. XXIV. $2^{a}$ ed. São Paulo: Boitempo, 2017, p. 824. - N.T.]
} 
- a saber, que a guerra e o crédito permanecem sendo, no curso de todo o capitalismo, armas estratégicas do capital. De modo que a acumulação primitiva [49] e suas forças telúricas de desterritorialização não cessam de se repetir e de se diferenciar para prosseguir melhor acelerando tanto quanto possam - o processo de dominação e de mercantilização de tudo o que existe. Em outras palavras, tanto no centro quanto na periferia, a acumulação primitiva é a criação continuada do capitalismo por ele mesmo.

O capitalismo é, desde o início, mercado mundial. Eis por que não seja analisável senão enquanto economia-mundo ${ }^{2}$. Isso que Marx chamou de "acumulação primitiva" (ou no “original”: ursprüngliche Akkumulation) para enunciar o sentido capital $^{3}$ desta primeira desterritorialização a princípio produzida pela guerra, pela conquista e pelas invasões, se desdobra ao mesmo tempo no "Novo Mundo", que acabávamos de "descobrir" (colonização externa) e na Europa (colonização interna). Afinal, a acumulação primitiva não criou as condições econômicas do capitalismo e a divisão internacional do trabalho - desenhando uma cisão geopolítica entre o Norte e o Sul de um mundo que ainda é o nosso - sem instaurar as hierarquias de sexo, de raça, de idades e de civilizações sobre as quais se sustentam as estratégias de divisão, de diferenciação, de desigualdades que atravessam a composição de classe do proletariado internacional.

Há de se retomar, portanto, em extensão e em intenção, o locus classicus da descrição das guerras de acumulação a partir deste momento em que, entre os séculos XV e XVI, os senhores feudais e a burguesia incipiente desencadeiam uma guerra civil na Inglaterra contra os camponeses, os artesãos e os trabalhadores diaristas rurais para a privatização das terras comunais. A destruição da estrutura comunitária dos vilarejos e dos focos de trabalho doméstico, o abandono das culturas de subsistência e a expropriação de fazendas reduzem a população à miséria e constrangem à mendicância e à vagabundagem um número crescente de expropriados (sem-terra) aos quais não [50] se deixa outra opção senão o extermínio ou a disciplinarização à marcha forçada rumo ao salário. Simultaneamente, os cercamentos (enclosures), a concentração de terras e o reagrupamento de posses em toda a Europa - uma

\footnotetext{
${ }^{2}$ Economia-mundo é um conceito forjado por Fernand Braudel e desenvolvido por Immanuel Wallerstein. Indica que o sistema capitalista inclui uma desigualdade hierárquica de distribuição que se baseia na concentração de produção relativamente monopolizada e em certas zonas limitadas, que se tornam sedes de maior acumulação de capital - o que implica no reforço das estruturas estatais e do incremento dos monopólios (N. T.).

${ }^{3}$ Em referência ao pecado original, segundo a famosa frase: "Essa acumulação primitiva desempenha na economia política aproximadamente o mesmo papel do pecado original na teologia" (Karl Marx, op.cit. p. 1167). [Karl Marx, 2017, p. 785 - N.T.]
} 
Europa submetida a estas "legislações sanguinárias" que Marx analisou demoradamente e que, por sua vez, ressuscitavam da escravidão ${ }^{4}$ antes mesmo de generalizar a prática do internamento como quadro do trabalho forçado - se duplicam em uma apropriação das "terras sem dono" das "Américas".

A conquista - quer dizer, o saqueio das riquezas naturais e minerais aliado à exploração agrícola das "terras improdutivas", resultará em um verdadeiro genocídio das populações indígenas, cujo "vazio" 5 “" será preenchido pelo tráfico de escravos graças à "transformação da África numa reserva para a caça comercial aos negros". "Eis aí os procedimentos idílicos da acumulação primitiva que marcam a aurora da era capitalista ${ }^{6 *}$, e que continuam: "A escravidão direta é o pivô de nosso industrialismo atual, bem como as máquinas, o crédito, etc.”, escreve Marx ainda em uma carta de $1846^{7}$. De tal modo que a acumulação primitiva se confunde com a conjunção capitalística de todos estes processos que jamais se encontrariam sem o ilimitado da violência levada do interior ao [51] exterior em um tipo de guerra antropológica que não tarda em adotar o termo pacificação $o^{8}$.

Os fluxos de crédito, a dívida pública (operando "como um dos agentes mais enérgicos da acumulação primitiva") e a guerra da conquista se fomentam e se reforçam mutuamente em um processo de desterritorialização imediatamente mundial. "O sistema de crédito público, quer dizer, das dívidas públicas" invade definitivamente a Europa ao passo que "o regime colonial, com seu comércio marítimo e suas guerras comerciais, lhe serve de estufa". A relação estreita entre a guerra e o crédito - e o nascimento deste último pelas necessidades financeiras do primeiro em sua potência de projeção em Guns and Sails $^{9}$ - determinam a estrutura mundial do

\footnotetext{
${ }^{4}$ Pensar aqui no ato promulgado em 1547 em nome de Edouard VI: aquele homem que permanecer durante três dias sem trabalho será considerado em delito flagrante de vagabundagem. Os juízes "devem imediatamente marcar o referido ocioso sobre sua testa pela letra $\mathrm{V}$, com o auxílio de um ferrete em brasas, e adjudicar esta pessoa viva, cuidadosamente, ao apresentador (ou seja, ao denunciante) para que este se torne seu escravo, para que o denunciante possua e tenha o referido escravo à disposição de si mesmo, de seus executores ou servidores pelo período de dois anos subsequentes". A fuga será punida por um castigo corporal, por uma nova marcação - um S - e por sua condenação à escravidão perpétua. A reincidência de fuga será punida de morte. Cf. Borislaw Geremek (éd.), Truands et misérables dans l'Europe moderne (1350-1600), Paris, Gallimard/Julliard, 1980, p. 98-99.

${ }^{5}$ Ver o catálogo aterrorizador dos efeitos da colonização espanhola realizado em 1542 por Las Casas em sua Brevísima relación de la destrucción de las Indias.

${ }^{6}$ Karl Marx, op. cit., p. 1212-1213. [Karl Marx, op.cit., p. 821 - N.T.].

${ }^{7}$ Karl Marx, carta a Annenkov, 28 de dezembro de 1846 (Oeuvres, t. I, op.cit., p. 1438).

${ }^{8}$ Retomando quase à letra o texto dos Decretos espanhóis relativos aos “Índios", Tzvetan Todorov escreve: "Não são as conquistas o que se deve banir, é a palavra "conquista"; a "pacificação" não passa de uma outra palavra para designar a mesma coisa". (La Conquête de l'Amérique. La question de l'autre, Paris, Seuil, 1982, p. 220).

${ }^{9}$ Cf. Carlo M. Cipolla, Guns and Sails in the Early Phase of European Expansion, 1400-1700, Londres, Collins, 1965 .
} 
processo de acumulação desenvolvido após 1492. (Antes da descoberta da América, insiste J. M. Blaut, "Os europeus não eram em nada superiores em relação aos não-europeus ${ }^{10}$. ") Quaisquer que sejam os precedentes mercantis e usurários, a origem do financiamento assume aqui uma nova faceta, inconfessável, que faz toda a diferença. "Com as dívidas públicas, nasceu um sistema de crédito internacional que esconde frequentemente uma das fontes da acumulação primitiva em um ou outro povo. [...] Uma grande parte do capital que, hoje, faz sua aparição nos Estados Unidos sem certidão de nascimento, não é senão sangue infantil de fábricas capitalizadas ontem na Inglaterra ${ }^{11} . "[52]$

E inversamente, mais primitivamente, em conseguinte, é o sangue africano que cimenta os tijolos das manufaturas e dos bancos de Liverpool ou de Manchester. Por trás da extrema sofisticação matemática do financiamento, há sempre a "ninhada de bancocratas, financistas, rentistas, corretores, agentes de câmbio, homens de negócios e lobos da bolsa" descrita por Marx.

\section{1/ A guerra contra as mulheres}

Sistematizando trabalhos italianos e americanos realizados desde os anos 1970 no contexto do International Feminist Collective, Silvia Federici não hesita em relacionar o destino das mulheres na Europa àquele das populações colonizadas pela Europa em um livro, cujo título, inspirado por A Tempestade, de Shakespeare, e pela retomada anticolonialista do personagem do Calibã, vale por um manifesto: $O$ Calibã e a bruxa ${ }^{12}$. O nascimento do capitalismo, explica Federici em seu livro, não é somente sinônimo de uma guerra contra os pobres, ele "se acompanha de uma guerra travada contra as mulheres ${ }^{13}$ " para colocá-las a serviço da divisão social do trabalho e dos cercamentos (enclosures) de todas as formas de relação humana - uma e outra passando por uma nova ordem sexual que acumula as divisões

\footnotetext{
10 J.M.Blaut, The Colonizer's Model of the World: Geographical Diffusionism and Eurocentric History, New York, Guilford, 1993, p. 51.

${ }^{11}$ Todas as citações são extraídas do capítulo XXXI do livro I do Capital. Para retomar a formulação de Maurice Dobb: "É a expropriação dos outros que é a essência do processo de acumulação, e não a simples aquisição de categorias particulares de riquezas pelos capitalistas". Maurice Dobb, Paul M. Swezzy, Du féodalisme au capitalisme: problèmes de la transition, t. I, Paris, Maspero, 1977, p. 91.

${ }^{12}$ Silvia Federici, Caliban et la Sorcière (2004), Genève, Entremonde, 2014. Uma primeira versão do trabalho já havia sido publicada vinte anos mais cedo na Itália junto de Leopoldina Fortunati: Il Grande Calibano. Storia del corpo sociale ribelle nella prima fase del capitale, Milano, Franco Angeli, 1984. [A tradução para o português teve de esperar até 2017 para ser publicada pela Editora Elefante depois do trabalho do coletivo feminista de tradução "Sycorax", nome herdado da mesma bruxa que intitula o trabalho de Federici. - N.T.].

${ }^{13}$ Silvia Federici, op.cit., p. 23. [Silvia Federici, Calibã e a bruxa, São Paulo, Elefante, 2017, p. 29-30 - N.T.].
} 
na produção e reprodução da força de trabalho. A degradação e a diabolização da mulher (“casada com o diabo"), a destruição dos poderes dos quais ela antes dispunha, a criminalização da contracepção e das práticas “mágicas” de cuidado privam as mulheres do controle sobre seus corpos, que se tornam doravante propriedade dos homens, propriedade garantida pelo Estado, [53] e parte da implementação da população ao trabalho ${ }^{14}$. Assim são definidas as condições da atribuição das mulheres ao trabalho de reprodução biológica, econômica e "afetiva" da força de trabalho.

“Trabalho não produtivo", explicam doutamente os economistas clássicos e um bom número de marxistas, uma vez que situado a montante da valorização do capital e, em consequência, como trabalho não pago, algo da ordem de um recurso natural e de um bem comum, mas regulado no domínio das (bio)políticas natalistas e famílialistas ferozmente promovidas pelo mercantilismo. A partir de Maria Mies, Silvia Federici pode assim traçar um paralelo entre o trabalho de reprodução não pago das mulheres (que vem acompanhado da apropriação de seus ganhos pelos trabalhadores homens) e o trabalho forçado dos escravos; e estudar a maneira com que a "guerra contra as mulheres", visando a sua disciplinarização, se inscreve no domínio de um novo tipo de patriarcado, o patriarcado do salário ${ }^{15}$.

Com as suas centenas de milhares de execuções, a "caça às bruxas" é o episódio mais sanguinário desta guerra contra a autonomia e a liberdade das mulheres empreendida desde o fim da Idade Média ${ }^{16}$. A “caça às bruxas" não é a marca infame de um Deus medieval saído da "história das mentalidades", mas o próprio sabá do capital. [54]

É no funcionamento mais cotidiano de uma "arte de governar" que não é "nem a soberania nem o poder pastoral ${ }^{17 ، “}$ que as campanhas militares de "evangelização" permitirão a exportação

\footnotetext{
${ }^{14}$ Michelet insiste que as "bruxas foram, sobretudo para as mulheres, a única e exclusiva médica". La Sorcière [1862], Paris, Julliard, 1964, p. 110. [Jules Michelet, A feiticeira, Rio de Janeiro, Nova Fronteira, 1992, p. 105 N.T.].

15 "Se é verdade que os trabalhadores homens não se tornaram formalmente livres a não ser com o novo regime do salário, o grupo de trabalhadores que, na transição ao capitalismo, mais se aproximaram da condição de escravidão foi o das mulheres da classe trabalhadora." A separação entre produção e reprodução torna então possível "o desenvolvimento de um uso especificamente capitalista do salário [...] como um meio de acumulação de trabalho não pago". (Silvia Federici, op. cit., p. 199, p. 148). [Silvia Federici, op. cit., p. 195, p. 146 - N.T.]

${ }^{16}$ Sobre este último ponto, além de Silvia Federici, ver Maria Mies, Patriarchy and Accumulation on a World Scale, Londres, Zed Books, 1986, p. 78-81.

17 Michel Foucault, Sécurité, territoire, population. Cours au Collège de France (1977-1978), Paris, Gallimard/Seuil, 2004, p. 242 (leçon du 8 mars 1978). [Foucault, Michel. Segurança, território e população: Curso dado no Collège de France (1977-1978). São Paulo: Martins Fontes, 2008, p. 327 (Aula de 8 de março de 1978) - N.T.]
} 
da caça às bruxas para o Novo Mundo, no momento em que a resistência dos "índios" contribuirá para por fim ao mito do Bom Selvagem ${ }^{18}$ e para declarar as mulheres, bastante implicadas nas revoltas indígenas, essencialmente perigosas para a ordem colonial. (Mas é o Calibã, e não sua mãe Sycorax - "bruxa” de quem Shakespeare não havia calado toda extensão de poderes e influência sobre seu filho - que se tornará o herói dos revolucionários latinoamericanos...) Inversamente, e sob o risco de desregular as cronologias mais estabelecidas, a estratégia política de extermínio dos Selvagens poderá ter influenciado o massacre dos protestantes, inspirando inteira e permanentemente a caça às bruxas (sodomitas e canibais) em nossa velha Europa ameaçada pela turba damnationis dos pobres ${ }^{19}$. De modo mais geral, Michel Foucault soube demonstrar desde o fim do século XVI o curso desta "espécie de repercussão, sobre as estruturas jurídico-políticas do ocidente, da prática colonial”. E de explicar:

\begin{abstract}
Não se deve jamais esquecer que a colonização, com suas técnicas e suas armas políticas e jurídicas, certamente transportou os modelos europeus aos outros continentes, mas que ela teve também numerosas repercussões sobre os mecanismos de poder no Ocidente, sobre seus aparelhos, instituições e técnicas de poder. Houve toda uma série de [55] modelos coloniais que foram devolvidos ao Ocidente, o que fez com que o Ocidente pudesse praticar também sobre si mesmo uma espécie de colonização, um colonialismo interno ${ }^{20}$.
\end{abstract}

De tal modo que as voltas, reviravoltas e repercussões do ciclo de reciprocidade histórica do nacionalismo, do racismo e do sexismo são, em todos os sentidos, constitutivas da potência ecumênica de globalização capitalística do mundo nesta guerra permanente que lhe serve de vetor e tensor. Que esta ecumenia não possa se conceber sem as "tecnologias" de biopoder e uma biopolítica contemporâneas à emergência do capitalismo, de que as colônias são também laboratório, lança uma luz bastante crua sobre a realidade supostamente "progressista" da transição, que se traduziria melhor em termos de cortes continuados.

\footnotetext{
${ }^{18}$ Pensemos no capítulo "Sobre os coches" nos Ensaios de Montaigne, sobre a agonia desse "mundo infantil" que era a América.

${ }^{19}$ Cf. Luciano Parinetto, Streghe e Potere: Il Capitale e la Persecuzione dei Diversi, Milano, Ronconi, 1998, p. 22: "Se os índios foram tratados como as bruxas exteriores ao Velho Mundo, por sua parte, as bruxas do Velho Mundo foram eliminados no emprego das técnicas de extermínio experimentados no Novo Mundo. Ainda que todos esses que se opusessem ao poder constituído do Velho Mundo tenham terminado sendo tratados como os índios da Europa." Jean Bodin, este "precursor" da economia política que é também autor de uma Demonomia, é um demonstrador central desta concepção "unitária" eminentemente moderna.

${ }^{20}$ Michel Foucault, "Il faut défendre la société." Cours au Collège de France (1976), Paris, Gallimard/Seuil, 1997, p. 89, destacamos (leçon du 4 février 1976). [Michel Foucault, Em defesa da sociedade. Curso no Collège de France (1975-1976), São Paulo: WMF Martins Fontes, 2010, p. 86 (Aula de 4 de fevereiro de 1976) - N.T.].
} 


\section{2/ Guerras de subjetividade e modelo majoritário}

Em seu curso no Collège de France intitulado Segurança, território e população, Foucault tenta alargar o sentido da guerra e a tipologia das guerras que tiveram curso durante o primeiro período da acumulação primitiva. Para fazê-lo, o autor chama nossa atenção a um aspecto geralmente ignorado sob as "grandes lutas sociais" que marcaram a transição do feudalismo ao capitalismo - dentro das quais a "guerra de camponeses" (1524-1526) é um dos episódios mais marcantes.

Foucault observa que a "transição" foi o palco de um tipo específico de guerra, cujo jogo era os modos de subjetivação e a conduta dos comportamentos. O "pastorado" cristão, que exercia um poder subjetivo de controle sobre a conduta dos indivíduos ("Foi necessário tornarse sujeito para tornar-se indivíduo" - e sujeito em todos os sentidos da palavra), entra em crise sob "o assalto de contra-condutas", destas [56] "insurreições de condutas", que ele qualifica de "revoltas pastorais", contra as novas condições econômicas de governo dos comportamentos. A passagem do "governo das almas" ao "governo político dos homens" não consiste em uma simples transferência das funções pastorais da Igreja ao Estado. Tem de haver, em vez disso, ao mesmo tempo a intensificação das formas espirituais de controle das condutas dos indivíduos (tão bem quanto a Reforma, a Contra Reforma exerce "uma influência sobre a vida espiritual e material dos indivíduos muito maior do que no passado ${ }^{21 ،}$ ) e a extensão de sua eficácia temporal, reorientada por esses dispositivos de "governamentalização da res publica 22، que colocam a nova ética teológica do trabalho e da riqueza a serviço da disciplinarização e da inserção das populações no trabalho forçado.

O pecado capital não será mais a avareza, mas a preguiça, fruto da "fraqueza da disciplina" e do "afrouxamento da moral", que é preciso reduzir na passagem da desordem à ordem. O que explica também, assim como sublinhava Foucault em A história da loucura, que “a relação entre a prática de internação e as exigências do trabalho não são inteiramente definidas [...] pelas condições econômicas ${ }^{23}$ ". Ora, o imperativo de trabalho é tão

\footnotetext{
${ }^{21}$ Michel Foucault, Sécurité, territoire, population, p. 235 (leçon du 8 mars 1978). [Michel Foucault, Segurança, território e população, p. 308 (Aula de 8 de março de 1978). - N.T.].Ver justo o início deste curso, onde se é colocada a questão das "insurreições de conduta" que encontramos até dentro da Revolução Russa.

${ }^{22}$ Ibid., p. 242. [Michel Foucault, Segurança, território e população, p. 317 - N.T.].

${ }^{23}$ Michel Foucault, Histoire de la folie à l'âge classique (1961), Paris, Gallimard, 1972, p. 85. [Michel Foucault, História da Loucura: na Idade Clássica, São Paulo, Perspectiva, 2014, p.73-74. - N.T.].
} 
indissociavelmente econômico e moral que se depara com inúmeras resistências, forçando a conjugar a lei civil e obrigação moral.

A importância e a radicalidade das guerras de subjetividade na Europa e no Novo Mundo se manifestam na destruição que a acumulação primitiva opera não somente no que tange às condições materiais da vida, mas também quanto aos territórios existenciais, aos universos de valores, à cosmologia e às mitologias [57] que estavam no fundamento da "vida subjetiva" dos povos colonizados e dos pobres do mundo dito "civilizado". A desterritorialização despoja os colonizados, as mulheres e os proletários de sua vida "a-orgânica", segundo a expressão de Deleuze e Guattari que é preciso redirigir em direção à análise foucaultiana. De fato, o biopoder não pode investir a vida como administração das condições “biológicas" da espécie pelo Estado (fecundidade, mortalidade, saúde, etc.) senão porque a acumulação primitiva foi previamente agente da destruição desta dimensão "subjetiva”. As guerras de subjetividade não são, portanto, "suplementos" do capital em sua face "subjetiva", elas constituem a especificidade mais "objetiva" das guerras empreendidas contra as mulheres, os loucos, os pobres, os criminosos, os trabalhadores diaristas, os operários, etc. Estas não se contentam em “desfazer” o adversário (para melhor negociar um tratado de paz, segundo a concepção clássica da guerra interestatal), uma vez que visam precisamente a uma "conversão" da subjetividade, a uma conformação dos comportamentos e das condutas à lógica de acumulação do capital e de sua reprodução.

Nesse sentido, a produção de subjetividade é ao mesmo tempo a primeira das produções capitalistas e um objeto primordial da guerra e da guerra civil. A formatação da subjetividade é seu jogo estratégico, algo que reencontraremos ao longo de toda a história do capitalismo. Para Félix Guattari, de quem tomamos emprestado o termo, as "guerras de subjetividade" são as guerras políticas de "formatação" e de "pilotagem" da subjetividade necessária à produção, ao consumo e à reprodução do Capital. Elas não são tampouco estrangeiras às lutas ferozes que se desenrolam no interior dos movimentos insurrecionais e de contestação para a definição das formas de organização e de subjetivação da máquina de guerra revolucionária (militância, modalidade de ação, estratégia, prática, etc.). Segundo Michel Foucault, elas constituem a trama da resistência e da invenção de uma subjetivação "outra" que achamos não apenas em toda experiência de ruptura revolucionária ${ }^{24}$, mas também em qualquer deslocamento que lhe tenha

\footnotetext{
${ }^{24}$ Michel Foucault, Securité, territoire, population, op.cit., p. 234: "nos processos revolucionários que tinham outros objetivos completamente, outras apostas completamente, a dimensão de insurreição de condutas a dimensão da revolta de Conduta esteve sempre presente". [Michel Foucault, Segurança, território e população, op.cit., p. $306-$ N.T.]
} 
feito pensar, uma vez que a passagem à ética de uma "vida militante" pela parrhesía é ela mesma uma "guerra contra a outra ${ }^{25 ،}$ vida.

Os processos violentos de desterritorialização que estão no âmago da acumulação primitiva (compreendido aqui no sentido mais estreito do termo, até à caça às bruxas ${ }^{26}$ ) e da globalização que a acompanha são, portanto, sempre indissociáveis da guerra de subjetividade. A construção do "modelo majoritário" do Homem, macho, branco e adulto, transformando as mulheres em minoria de gênero e os colonizados em minoria de raça, é um dispositivo estratégico que realiza-se necessariamente simultaneamente nas colônias do Novo Mundo e na Europa, onde sabe-se demasiadamente bem que as "diversidades doam a Satã maravilhosas facilidades ${ }^{27 ،}$. De modo que a primeira construção europeia torna-se esta de um Little Big Man surgido deste espaço de terror fomentando todas as "trocas" estratégicas ao benefício da formação continuada de um proletariado mundial.

As relações de poder e as divisões estabelecidas pelo modelo majoritário vão se inscrever profundamente na organização das relações de exploração, tanto na metrópole quanto em suas periferias. Pois é com a acumulação primitiva e como acumulação continuada do capitalismo que o modelo maioria (homens)/[59] minorias (mulheres) funciona no interior do assalariado europeu cruzando-se com a exploração de classe.

A guerra contra as mulheres produz uma diferenciação e uma divisão sexual do trabalho que se revela estratégica para a história da acumulação do capital e das lutas que se lhe opuseram. Em uma sociedade em pleno curso de monetarização, as mulheres não possuem acesso ao dinheiro senão indiretamente através do salário de operário masculino, relação diante da qual elas se encontram em uma situação de dependência e inferioridade. Dominado segundo a lógica de classe, o assalariado masculino devém dominante na lógica do modelo majoritário/minoritário. O salário e suas modalidades de distribuição são sinônimos de uma forma de dominação sobre a mulher e de promoção forçada da família nuclear "burguesa" no

\footnotetext{
${ }^{25}$ Michel Foucault, Le Courage de la vérité. Le gouvernement de soi et des autres II, Cours au Collège de France (1983-1984), Paris, Gallimard/Seuil, 2009. [Michel Foucault, A Coragem da Verdade. O Governo de Si e dos Outros II, Curso no Collège de France (1983-1984), São Paulo, WMF Martins Fontes, 2011].

${ }^{26}$ Dado que os processos em feitiçaria se acompanhavam da confiscação de bens das "culpadas", e que não se tardou a reconhecer aí uma furiosa alquimia transformadora do sangue das mulheres em ouro. Há, portanto, uma economia política da caça às bruxas.

${ }^{27}$ É o que se diz dos bascos: "completamente impróprios para a lavoura, péssimos artesãos e pouco versados aos trabalhos manuais, e [cujas] mulheres [são] pouco ocupadas, em suas famílias, como estas que não têm quase nada a arrumar". Cf. Pierre de Lancre, Tableau de l'inconsistance des démons, magiciens et demons (1612), éd. N. Jaques-Chaquin, Paris, Aubier, 1982, p. 72, p. 77.
} 
mundo operário, que retomará dela o refrão até nas suas correntes mais revolucionárias. "Antifeminismo proletário" (segundo a expressão de Thönessen) e defesa dos direitos da mulher reduzida à sua condição de mãe e de dona de casa andam de mãos dadas. Segundo a constatação de Maria Mies: “A proletarização dos homens repousa sobre a transformação das mulheres em donas de casa. O Homenzinho branco tinha também sua própria “colônia”, a saber, a família e uma mulher no ambiente doméstico. ${ }^{28 ،}$

A despeito de certas críticas feministas, a microfísica foucaultiana do poder se revela aqui um instrumento indispensável para levar em conta a maneira com a qual o poder passa também através dos dominados, visto que a "micropolítica" se torna o terreno privilegiados das dinâmicas de divisão, de diferenciação, de antagonismo. É, na verdade, toda a "composição de classe" do proletariado que é assim atravessada pelas linhas de fratura que são a origem de verdadeiras "guerras civis" moleculares, irredutíveis a qualquer espécie de conflito ideológico.

Ashis Nandy descreveu notavelmente a maneira pela qual, na Índia, a construção do modelo majoritário pelos colonizadores britânicos passa essencialmente pelas mesmas etapas desde [60] o estabelecimento de uma nova hierarquia "colonial das identidades sexuais", segundo a qual "o masculino é superior ao feminino, e o feminino é, por sua vez, superior à feminilidade no homem" através da desvalorização da cosmologia andrógina indiana ${ }^{29}$. A normalidade é identificada ao homo europaeus adulto, ao mesmo tempo viril, competitivo, animado por um espírito guerreiro, rejeitando a impotência dos afeminados, ao passo que a criança, como o colonizado, é remetida ao mundo "primitivo", sinônimo de uma situação de inferioridade que apenas o "desenvolvimento" (o processo de civilização) permitirá corrigir.

O dispositivo de poder maioria/minorias estria a guerra de subjetividades da colonização interna e da colonização externa estabelecendo hierarquias de raça, sexo, mas também de civilização. Esta última é perfeitamente "performada" pela afirmação schmittiana segundo a qual os índios "não dispunham da força cognitiva apropriada à racionalidade da Europa cristã: [...] A superioridade intelectual estava inteiramente do lado europeu ${ }^{30 ، ،}$. O que explica também que a descoberta do novo mundo tenha podido desempenhar um papel de "autêntico evento

\footnotetext{
${ }^{28}$ Maria Mies, op.cit., p. 110.

29 Ashis Nandy, L'Ennemi intime (1983), Paris, Fayard, 2007, p. 95.

${ }^{30}$ Carl Schmitt, Le Nomos de la terre, Paris, PUF, 2001, p. 133.
} 
epistemológico" compensando o descentramento cósmico de Galileu por um "recentramento terrestre-imperialista da Europa" ${ }^{\prime 1}$.

A “acumulação primitiva” deverá então ser chamada primeira (inicial na tradução de J.P. Lefebvre, ou originária: ursprünglich) na medida em que já aí se esboça uma divisão internacional do trabalho com as hierarquias que são "classe" precisamente porque são também de gênero, de raça, de civilização. Que seja uma acumulação de potência e de poder que impeça de simplificar a economia-mundo de emergir em oposição à luta de classes na metrópole e a luta de raças nas colônias, contanto que o dispositivo maioria/minorias seja operacional, com modalidades diferentes, nos dois lados do Atlântico. Há identidade de natureza e diferenças de regimes com múltiplos cruzamentos.

\section{3/ Liberalismo e colonização: o caso Locke}

Muito se estudou a biografia intelectual e o aparelho doutrinal de John Locke a fim de se verificar se este era mesmo o pai fundador do liberalismo político, na origem de toda a tradição americana, e "o decano da economia política moderna" (Marx). Apesar de uma importante literatura anglo-saxônica praticamente desconhecida na França, interessou-se muito menos por sua longa carreira colonial e por suas incidências sobre o conjunto de sua filosofia, na qual "a América" é onipresente. O estudo do liberalismo de Locke - e do liberalismo, pura e simplesmente - se encontrará singularmente enriquecido por isso e reinscrito na história (ou na contra-história) que refazemos aqui em linhas gerais.

Locke foi, na verdade, secretário dos Lordes proprietários da Carolina (1668), onde possuía terras beneficiando-se da regra constitucional em cuja redação ele mesmo havia contribuído e segundo a qual "todo cidadão livre da Carolina exerce um poder e uma autoridade sem limites [absolute Power and Authority] sobre seus escravos negros ${ }^{32 ،}$. A partir de 1673, ele se torna secretário e tesoureiro do Council of Trade and Foreign Plantations (1673), bem como acionista de diferentes empresas, dentre as quais a Royal African Company que geria o tráfico negreiro e obtinha o monopólio da África ocidental.

\footnotetext{
31 Matthieu Renault, L'Amerique de John Locke. L'expansion coloniale de la philosophie européenne, Paris, Éditions Amsterdam, 2014, p. 23-24.

32 John Locke, Constitutions fondamentales de la Caroline, art. CX (in Deuxième Traité du gouvernement civil, Paris, Vrin, 1967, p. 245). Locke adiciona “absolute Power" na primeira redação do artigo.
} 
Ora, é sobre este negócio extremamente lucrativo que repousava o modelo "agrícola" inglês de colonização do qual Locke era o ardente defensor. Que haja aí uma contradição imediata com as linhas de abertura do primeiro dos dois Tratados do governo ("Slavery is so vile and miserable $e^{33}$ ”...), que condenam a escravidão e contribuem a assentar sua reputação de filósofo liberal, é uma evidência que não se solucionará inventando distinções sutis entre "contradição com a prática" e "contradição de princípio" ou entre "racismo forte" e "racismo leve". É sobretudo a realidade contraditória do universalismo do modelo liberal que aqui se implementa filosoficamente a serviço e em nome de um Englishman compreendendo um racismo de civilização em sua constituição colonial/colonialista, em um tempo em que o conceito moderno de raça ainda não é biologicamente - quer dizer, "cientificamente" estabelecido e em que o regime legal da escravidão de plantation se negocia sob a pressão de um grupo de Royal Adventurers ao qual Locke pertence de pleno direito.

Eis o que explica também que a filosofia inglesa poderá, sem contradição, em sua perspectiva liberal, estigmatizar a "escravidão" política que a monarquia absoluta queria introduzir na Europa, submetendo assim todas as nações a um estado de guerra permanente dominado pela arbitrariedade contra todos. A descrição que é pintada a partir disso (o rei “degenerou numa besta selvagem") não deixa de evocar a Lenda negra da "técnica espanhola" de colonização por espoliações sistemáticas (by raping and plunder), sabiamente fomentada em um contexto de rivalidades "mercantilistas" entre as grandes potências europeias. Pois é disto que é acusada a monarquia absoluta: confundir a Europa com a pior das colônias, sob o risco de fomentar "sedições eternas" e de dar à luz princípios próprios ao encorajar os "levantes populares", ameaçando o próprio princípio de governo. Na advertência à tradução francesa de David Mazel, publicada em Paris no ano III da República (1795), o projeto político de Locke se enuncia em uma [63] fórmula de um classicismo bastante soloniano: "encontrar um meio entre estas extremidades ${ }^{34 ،}$.

Uma vez que um "homem não pode, por contrato ou por consentimento, se tornar escravo de outro homem, nem se assujeitar ao poder absoluto e arbitrário 35،, é ao "povo” que cabe estar

\footnotetext{
33 Cf. John Locke, Premier Traité du gouvernement civil, § I: “A escravidão é para um homem um estado tão vil, tão miserável e tão diretamente contrário ao caráter liberal que é difícil imaginar como um inglês, ainda menos um homem honesto [gentleman] poderia argumentar a seu favor."

${ }^{34}$ John Locke, Avertissement au Traité du gouvernement civil, ed. S. Goyard-Fabre, Paris, Garnier-Flammarion, 1992, p. 137. As expressões "sedições eternas" e "levantes populares" foram retiradas desta Advertência.

35 John Locke, Le Second Traité du gouvernement. Essai sur la véritable origine, l'étendue et la fin du gouvernement civil (IV, "De l'esclavage”, sec. 23) Fazemos referência a seguir, no corpo do texto, ao capítulo e à seção do Second Traité.
} 
em "consentimento" à origem do poder político e da sociedade civil - "da sociedade política ou civil”, segundo o título do capítulo central do Segundo Tratado do governo civil. Seus membros recolocam seu "poder natural" entre as mãos da "comunidade" afirmando-se commonwealth pelo poder de "preservar a propriedade" (VII, sec. 85) sem ter de passar pela guerra, que é também para Locke, em bom europeu, a única verdadeira condição de escravidão uma vez que não é "nada além de um estado de guerra que persiste entre um conquistador legítimo e um prisioneiro". (IV, sec. 24). Se “é, portanto, evidente que a monarquia absoluta [...] é, na verdade, incompatível com a sociedade civil" (VII, sec. 90) porque ela é continuação da guerra por outros meios dirigidos contra seu povo, não é menos evidente que a sociedade civil será de responsabilidade de um povo de proprietários para o qual o problema político ao qual o liberalismo se identifica pela mediação de Locke - é aquele de um retorno (do recalcado) da escravidão dos "negros" da América sobre o solo europeu e a Inglaterra, do qual ele assegura a "prosperidade" pelos meios da guerra que são estes da diferença colonial. Como, efetivamente, as razias dos escravos e sua respectiva mercantilização poderiam emergir do direito da "guerra justa" sobre o palco europeu? Mas esta diferença colonial não é, ela mesma, essencialmente relativa, tendo em vista a condição dos pobres sobre o mesmo palco de operações?

É a um povo de proprietários que cabe exprimir o capitalismo nascente e seus conceitos de trabalho, de propriedade privada e de moeda que fazem falta aos colonizados até mesmo no estado de natureza do qual eles transgridem as regras. As terras são baldias, os espaços, vazios (vacuis locis) porque o "índio selvagem, que não conhece qualquer cerca" (V, sec. 26), não as submetem à "indústria humana" e ao trabalho de "valorização" ambos pressupostos no fundamento natural da "propriedade". Nômades, vivendo de colheita e de caça, eles não “trabalham" para dar a cada coisa seu próprio valor e se furtam ao mandado divino de fazer frutificar a terra: "Deus deu a terra [...] para o uso daqueles que seriam industriais e racionais (e o trabalho devia ser um título em sua posse)" (V, sec. 34). Eis uma primeira violação ao direito natural, à propriedade individual, à propriedade privada exclusiva (proprietas) da terra que o homem cerca por seu trabalho separando-a do que é comum dentro dos limites ("bastante modestos") da utilização que poderá fazer dela. Eis, ao menos indiretamente, uma primeira justificativa para a apropriação colonial destas terras indivisas e incultas (waste) da América pela implementação de uma política de cercamento que não poderia senão significar a expropriação sem consentimento de seus habitantes sem direito, nem mesmo natural (não passa 
à cabeça de Locke que se tem aqui, nesse ato de guerra e nessa perspectiva com base em Grotius $^{36}$, o princípio de explicação desses vacant places, vacant habitations após dois séculos de colonização europeia...).

A diferença de civilização se revela tão absoluta (“os modos desses povoados são [...] de

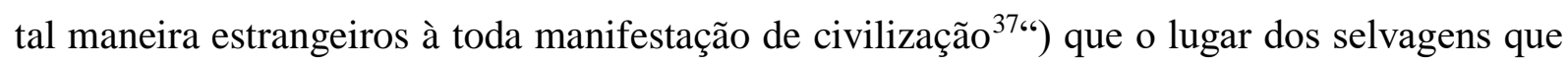
são considerados vivos "de acordo com a natureza" está longe de estar assegurado em um estado de natureza, no qual é próprio tornar compatíveis as "propriedades privadas" (V, sec. $\left.35^{38}\right)$ com “um estado de igualdade em que todo poder e [65] toda jurisdição são recíprocas". Este é um estado historicamente tão improvável que "as promessas e os mercados de troca" obrigando os homens, uns em relação aos outros, à verdade e ao respeito da palavra dada poderão acionar "um suíço e um índio nas florestas da América" (II, sec. 4 e 14)... O europeu na América virá assim encarnar a lei da natureza, que não é senão um puro cálculo interessado partilhado por estes que fazem o seu! Passando pelo trabalho que dá à terra todo o seu valor, a demonstração acabará de revelar todo seu anacronismo ao se fazer o balanço do presente: na América, "o rei de um território vasto e fértil é bem menos nutrido, abrigado e vestido do que um trabalhador diarista na Inglaterra" (V, sec. 41) em razão da diferença de rendimento entre um "acre de terra" cultivado aqui ${ }^{39}$ (em que o benefício é bem precisamente estimado em $5 £$ por Locke) e lá: “o rendimento total que um índio obtém da terra, tivéssemos de remetê-lo ao mercado daqui, não alcançaria uma proporção de um por mil" (V, sec. 43). Entre aqui e lá, o índio não passa por não ter sabido chegar a esta última etapa de natureza que é a invenção da moeda: em seu uso, "por via de consentimento", ela transforma a terra em capital destinado a produzir bens destinados ao comércio. Anunciando o fim da igualdade e dos limites naturais ligados à satisfação de necessidades, o dinheiro abre efetivamente a via para a apropriação ilimitada das terras e do trabalho, e para uma primeira forma de governo (ou de governamentalidade) entre os indivíduos tornados desiguais pelas "propriedades mais vastas e o direito que ela estabelece sobre elas" (V, sec. 36). Chegamos aqui à primeira forma de desenvolvimento, ao mesmo tempo

\footnotetext{
${ }^{36}$ Em De Jure Belli ac Pacis, livre II, chap. 3-4.

${ }^{37}$ John Locke, Essai sur la loi de la nature, Caen, Centre de philosophie et juridique de l'université de Caen, 1986, p. 45 (citado por Matthieu Renault, op.cit. p. 57).

38 "A condição da vida humana, que requer o trabalho e os materiais para a alcançar, conduz então necessariamente às propriedades privadas."

39 [Note-se aí a diferença continental a ser traduzida também. Para nós, leitores brasileiros, a relação espacial é inversa: aqui, em continente americano, é que um acre de terra não alcança a proporção de um por mil do rendimento das terras de lá. - N.T.]
} 
monetária e protojurídica (nesta ordem), de um Far West que se decompõe em war on waste ${ }^{40}$. Mas isto é para Locke um bem que precisa ser buscado pela sociedade, porque aumenta a riqueza global da qual se beneficia até o mais pobre dos trabalhadores... Um conto de fadas, devidamente retomado por Adam Smith em A Riqueza das nações a título de uma "previous [66] accumulation" desmontada por Marx (a riqueza das nações assegura a pobreza do povo).

Difícil de contradizer MacPherson uma vez que ele argumenta que a instituição do governo civil que surgirá deste estado de natureza monetarizada para proteger "a propriedade de cada um" torna a fazer da economia de mercado e de suas divisões de classe um fundamento permanente da sociedade civilizada ${ }^{41}$. É portanto como um degrau da civilização em um só mundo que Locke inscreverá o desenvolvimento do colonialismo na América na economia mundial do capitalismo nascente: "Eu pergunto, quem atribuiria um valor a dez mil ou a cem mil acres de uma terra excelente, fácil de cultivar e, ademais, bem provida de gado, mas situada no coração da América, se não existe lá qualquer possibilidade de comercializar com outras partes do mundo e de atrair o dinheiro pela venda de produtos? Esta terra não valeria a pena cercar" (V, sec. 50).

A plena racionalidade capitalística que se desdobra aqui em uma geopolítica colonial do estado de natureza obedece à lógica histórica da acumulação pelo "comércio" da apropriação do mundo. Ela permite ao filósofo encenar, reconstruir e mover na cena americana uma verdadeira ordem das razões para a expropriação sem consentimento dos camponeses ingleses, que jamais aparece como tal nos dois Tratados - salvo em seu resultado supostamente mais natural: os homens, não possuindo mais terras, terão a capacidade de adquirir por seu trabalho os meios monetários de subsistência transferindo o ganho que recompensa o trabalho do bolso de um outro ${ }^{42} \ldots$ Se as políticas de cercamento são, para Locke, "a pedra angular da via inglesa da colonização da América ${ }^{43 ،,}$, é o destino dos "pobres”, que é preciso a todo custo pôr ao trabalho, submetendo-os [67] ao regime das workhouses e das "escolas da indústria" para as

\footnotetext{
40 Segundo a expressão de Mark Neocleous, em War Power, Police Power, Edinburgh, Edinburgh University Press, 2014, p. 60.

${ }^{41}$ Eis o sentido da demonstração de C. B. MacPherson, La Théorie politique de l'individualisme possessif (1962), Paris, Gallimard, "Folio Essais", 2004, chap. 4.

${ }^{42}$ Segundo a explicação de Locke em suas Novas considerações sobre a elevação do valor da moeda, citado por Marx em anexo das Teorias sobre a mais-valia (ed. G. Badia, t. I, Paris, Éditions sociales, 2974, p. 428-429).

${ }^{43}$ Matthieu Renault, op. cit., p. 156.
} 
crianças, forçando-os ao engajamento na marinha ou deportando-os às plantations ${ }^{44}$, o que evoca a escravidão por seu dever de servidão em um mundo em que o comércio torna mais "próspero" do que nunca. Prova, se ainda fosse necessário, de que "o aumento do número de pobres deve vir de uma outra causa, que só pode ser a depravação moral e a corrupção dos costumes, a virtude e a indústria caminhando juntas bem como o vício e a ociosidade ${ }^{45 ، .}$.

Medem-se, logo, os limites da função civilizatória no trabalho após a introdução do dinheiro, que funda o princípio de racionalidade da acumulação ilimitada, dissociando a apropriação (da terra) e o trabalho (dos homens sem-terra) do qual se pode apropriar seguindo uma lei de natureza e de razão. O desenvolvimento pleno da racionalidade, coincidente com o esgotamento da persona ceconomica, é, desde então, um problema mais de apropriação e de expropriação do que de trabalho, e "o homem industrial" não é mais "o homem de razão" (the rational). Este pobre trabalhador submisso à autoridade do Estado que administra e disciplinariza sua força de trabalho mantendo-lhe sobre o circuito de subsistência mais curto possível, "from hand to mouth", e o menos apto possível a "elevar seus pensamentos para além dos problemas imediatos da vida" no dia a dia. À classe trabalhadora, tão limitada em suas possibilidades de aquisição de conhecimentos quanto de riquezas ${ }^{46}$, não poderia-se então conferir o direito de se insurgir, pois seu exercício depende, de direito, de uma escolha da razão e constitui, na verdade, $o$ único critério da cidadania ${ }^{47}$ - em sua diferença com a sujeição a um poder arbitrário e absoluto contra o qual o povo tem razão de se revoltar a fim de manter sua própria segurança e a garantia de seus bens, "que são o fim pelo qual entramos em sociedade" (XIX, sec. 222). Encontramos “a liberdade contra a escravidão" por exclusão inclusiva do novo proletariado, de quem a condição é considerada tão arduamente pelos economistas ingleses após 1660 que não há qualquer outro "equivalente moderno senão a conduta dos colonos brancos menos recomendáveis perante seu coloured labour ${ }^{48 ،}$. Branca ou negra, a força de trabalho, que constitui "o recurso | commodity : mercado | mais essencial, mais fundamental e mais

\footnotetext{
44 Estas são as recomendações de Locke em seu Relatório sobre os pobres - On the Poor Law and Working Schools, 1697 - apresentado ao ministro do Comércio e das Colônias. Cf. John Locke, Que faire des pauvres?, Paris, PUF, 2013, P. 29-30, P. 32.

45 Ibid., p. 26.

${ }^{46}$ Cf. John Locke, Essai philosophique concernant l'entendement humain, trad. Costes, ed. É. Naert, Paris, Vrin, 1989, p. 591 (IV, xx, 2).

${ }^{47}$ Cf. C. B. MacPherson, op. cit., p. 370-371.

${ }^{48}$ R.H. Tawney, Religion and the Rise of Capitalism, Penguin, 1948, p. 267 (citado por C.B. MacPherson, op.cit., p. 377).
} 
precioso 49 “, não é, definitivamente, o povo "político" onde cada um conduz sua compreensão pela razão para se doar por consentimento mútuo um "governo civil" e se constituir em “sociedade civil", na qual o legislativo é a "alma que [lhe] dá forma, vida e unidade" (XIX, sec. 212).

É esta ideia liberal de um contrato-consentimento, que funda o legislativo sobre a legitimidade do povo incorporando-o nele, que impõe a Locke uma concepção continuísta da servidão e diferencial da razão ${ }^{50}$, segundo a qual os seres incapazes de se governar por eles mesmos, em seu interior (as crianças, as mulheres, os loucos, os idiotas, e os pobres: labouring poor e idle poor) e em seu exterior (os selvagens), devem, a um título ou a outro, serem governados sem que eles o consintam.

Ela se funda sobre uma (geo)política da compreensão, articulando em um sentido novo as colonizações interior e exterior na "identidade de consciência" de um novo sujeito do governo de si e dos outros que se estabelece sobre esta história do estado de natureza onde cada homem é "proprietário de sua própria pessoa | man has a property in his own person |" (V, sec. 27). Desde Locke, que forja no Ensaio filosófico a respeito da compreensão humana a expressão nominal the Self, o assujeitamento (subjectio) ao trabalho se conjuga com a [69] propriação e a apropriação de um "Si" na construção de um sujeito possessivo de modo que este se confunde, no cruzamento do psicológico, do epistemológico, do jurídico, do político e do econômico com a invenção europeia da consciência liberal.

“O império que o Homem tem sobre este pequeno mundo, quero dizer, sobre seu próprio entendimento, é o mesmo que aquele que ele exerce nesse grande Mundo dos Seres visíveis ${ }^{51}$." Crítico da universalidade das "ideias inatas" impressas na alma por inseminação divina, o empirismo de Locke se ocupa de definir as operações reais do espírito (Mind), que afirmam por "reflexão" a identidade do pensar e do conhecer por uma consciência (consciousness) na qual a identidade a si (self-consciousness) é promessa de conquista do processo de totalização do saber e condição de realidade da responsabilidade da pessoa. O pensamento não é mais uma "substância" metafísica (Descartes), ele se torna o objeto de um trabalho e de uma apropriação (ele é appropriated), o que me torna responsável (accountable) enquanto Pessoa (moral e

\footnotetext{
${ }^{49}$ William Petyt, Britannia Languers (1680), p. 238 (citado por C.B. MacPherson, ibid.).

${ }^{50}$ Cf. Matthieu Renault, op.cit., p. 26.

${ }^{51}$ John Locke, Essai philosophique concernant l'entendement humain, op.cit., p. 76 (II, ii, 2: “The Dominion of Man, in this little World off his own Understanding, being much the same, as it is in the great World of visible things").
} 
jurídica), "capaz de Direito" e "responsável por seus atos" por esta "cons-ciência (con-science) da qual tenho [self-consciousness]". Uma cons-ciência (con-science), segundo o neologismo proposto por Pierre Coste em sua tradução realizada em estreita colaboração com Locke para dar-se conta daquilo que o filósofo, o pioneiro, chama "consciência de si ${ }^{52 ،}$, sem a qual o

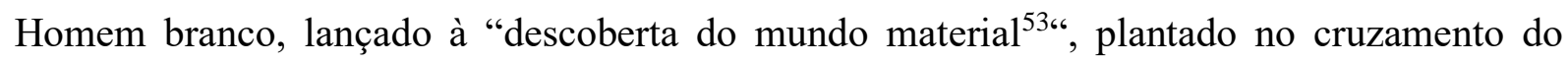
empirismo e do Império na mais estrita correlação entre poder econômico, poder cognitivo e poder normativo, não saberia conduzir sua compreensão - e comandar [70] sua nave - sobre o "grande oceano dos conhecimentos", como a Inglaterra soube "fazer funcionar o comércio" com outras nações do mundo. É todo este movimento de "reflexão" que está implicado na identificação ocidental da identidade do mesmo e da identidade de si, do "próprio" e da "propriedade" - de modo que é sobre esta identidade pessoal que faz que "um ser racional [ser] sempre o mesmo [personal identity, i.e. the sameness of a rational Being]" que deverão ser "fundado[s] todo o direito e toda a justiça das penas e das recompensas, da felicidade e da miséria, dado que é por isto que cada um se interessa por si mesmo ${ }^{54 ،}$.

Mas esta identidade pessoal deve certamente ser ela mesmo construída em uma autodisciplina concebida como uma aprendizagem da autoridade e do poder sobre si e sobre os outros, na qual a educação ("suited to our English gentry") e a submissão à matriz hierárquica da família patriarcal são a chave. Que Some Thoughts Concerning Education (publicado por Locke em 1693) tenha sido um best-seller durante todo o século XVIII nos fornece um índice certeiro, em plena ressonância com a ética puritana e responsável do capitalismo ${ }^{55}$ e o sistema de hábitos que ela se empenha em promover ${ }^{56}$. Bem mais do que uma simples instrução, tratase de "uma regulamentação da conduta infinitamente pesada e severa [...] penetra[ndo] todos

\footnotetext{
${ }^{52}$ Ver a longa nota de Pierre Coste em Essai philosophique concernant l'entendement humain, op.cit., p. 264-165 (II, XXVII, 9) e a análise que Étienne Balibar propõe dela em Identité et différence. L'invention de la conscience, Paris, Seuil, 1998.

${ }^{53}$ Cf. John Locke, Essai philosophique concernant l'entendement humain, op.cit., p. 463-464 (IV, III, 30), onde o filósofo desenvolve o paradigma "imperial" da navegação e da descoberta dos Novos Mundos como princípio de expansão do entendimento.

${ }^{54}$ Ibid., p. 265 (II, XXVII, 9), p. 271 (II, XXVII, 18).

${ }^{55}$ Cf. John Locke, Some Thoughts Concerning Education (1693).Sobre a primeira, para além da repressão do desejo ("a man may be able to deny himself of his desires"), ver as precisões maníanas do longo primeiro capítulo sobre a "Saúde"; para a segunda, será suficiente citar esta frase de conclusão: "nothing is likelier to keep a man within compass than the having constantly before his eyes the state of his affairs in a regular course of accounts" (§ 211). Arrisquemos a seguinte tradução para não perder a bússola (compass): "nada é mais apropriado em ajudar um homem a tomar conta de sua bússola (within compass) do que o hábito de ter sempre à vista o estado de seus negócios em contas exatas e em ordem".

${ }^{56}$ John Locke, Quelques réflexions sur l'éducation, § 18: “O grande negócio na educação é o de considerar quais hábitos te fazem prender a criança."
} 
os domínios da vida pública ou privada ${ }^{57 ، “}$ que está no coração desta civilização capitalista (para retomar mais uma palavra de Max Weber) e das guerras [71] de subjetividade que ela promove, em nome de uma universalidade proprietária que "instrui” os outros de sua exclusão inclusiva/inclusão exclusiva no modelo majoritário das guerras do Self. Pois não é necessário dizer que todos os homens, mesmo que de diferentes títulos, serão membros da "sociedade política ou civil” quando se trata de serem governados. O Self-service do liberalismo.

\section{4/ Foucault e a acumulação primitiva}

Diferentes autores da nebulosa dos estudos pós-coloniais criticam Foucault por ignorar amplamente a genealogia colonial do biopoder, exceção feita ao curso de 1976 no Collège de France, no qual a passagem que citamos serviria de hápax ${ }^{58}$. Outros autores, desta feita no campo dos estudos feministas, como Silvia Federici, censuram o filósofo francês e seu silêncio sobre a "caça às bruxas" e, mais geralmente, sua falta de interesse pela questão da "reprodução" e da disciplinarização das mulheres na longa duração das técnicas de poder e dos fenômenos de resistência por ele estudados. Tanto os primeiros quanto os últimos concordam em destacar a abstração discursiva da análise foucaultiana que indica o poder como um Primeiro Motor da História. [72]

Também entendemos que, se remontarmos a genealogia das técnicas disciplinares e do biopoder ao surgimento da acumulação primitiva, então a história, o funcionamento e as transformações sucessivas desses dispositivos de poder não podem e não devem ser separados da guerra em todas as suas modalidades, muitas delas explícitas. Nas diferentes modalidades existentes a partir do final do século XVII, esses dispositivos são a expressão privilegiada da continuação da guerra por outros meios, e a farão aparecer como analisadora das relações de poder. Esta é a lógica do trabalho de 1976, quando o filósofo não inverte a fórmula de

\footnotetext{
${ }^{57}$ Max Weber, L'Éthique protestante et l'esprit du capitalisme, Paris, Plon, 1964, p. 33.

${ }^{58}$ Michel Foucault, "Il faut défendre la société", op.cit. p. 89 [Michel Foucault, Em defesa da sociedade, 2010, p. 86 (Aula de 4 de fevereiro de 1976.) - N.T.]. Cf. Ann Laura Stoler. Race and Education of Desire. Foucault's History of Sexuality and the Colonial Order of Things. Durham e Londres: Duke University Press, 1995, pp. 7475: "Embora Foucault aborde a questão da colonização em cursos anteriores, é aqui que, pela primeira e única vez, vincula explicitamente o discurso da colonização interna na Europa à realidade de sua expansão externa - de uma maneira que não se encontra em nenhuma de suas análises anteriores. [...] Foucault não aprofundou esta ligação nem a desenvolveu mais" (tradução nossa). Como veremos, esta questão foi forjada levando-se em consideração a questão do colonialismo no curso de 1972-1973 (O poder psiquiátrico). Em defesa de Ann Laura Stoler, nenhum dos cursos havia sido publicado na época da publicação de seu livro.
} 
Clausewitz (conforme costumamos dizer ${ }^{59}$ ) e indica que, muito pelo contrário, o que houve foi o retorno de "um princípio muito anterior [...], uma espécie de tese simultaneamente difusa e precisa que circulou entre os séculos XVII e XVIII", segundo a qual a guerra deve ser entendida como uma "relação social permanente ${ }^{60 "}$ ". Isto o levará a estudar o aparecimento e a difusão de discursos que pela primeira vez conceberam a política como uma continuação da guerra.

Não podemos sustentar, portanto, que Foucault não se interessou pela época correspondente à acumulação primitiva. Por outro lado, certamente é verdade que ele a analisa do ponto de vista da constituição dos Estados no capitalismo nascente (da “governamentalização do Estado") e a partir da perspectiva das guerras de subjetividade que caracterizaram a transição do feudalismo para o capitalismo. Aqui chegamos ao tendão de Aquiles, onde o trabalho insubstituível de Michel Foucault sofre de uma grande limitação. $\mathrm{O}$ ponto de vista eurocêntrico, que é o dele (e até mesmo, em grande parte, "britânico-cêntrico" no que concerne à genealogia da "guerra racial", relatada - de maneira bastante aleatória - sob os efeitos das conquistas da Inglaterra [73] no curso de 1976) é problemático por si só e reduz o escopo das análises da constituição das relações de poder no capitalismo emergente forjado transversalmente nas duas costas do Atlântico. Os três aspectos que emergem (acumulação estatal, crise do poder pastoral sob o horizonte da "governamentalidade" definida em termos de estratégias e de táticas, possíveis efeitos de retorno da relação disciplinas/colonizados sobre os mecanismos de poder no Ocidente) devem, portanto, ser retomados e estendidos além dos limites que os caracterizam, uma vez que contribuem fortemente para problematizar a guerra como "cifra" ou algarismo da relação social do capital, impondo a análise do poder político como disciplinarização da guerra.

Isto porque as guerras de conquista e de predação do Novo Mundo ordenaram a automanifestação ampliada de outra instituição indispensável ao nascimento e à ascensão do capitalismo. A acumulação primitiva também é, talvez primordialmente, o acúmulo de poder e riqueza do Estado. Michel Foucault é, sem dúvida, quem o descreve da maneira mais relevante, ao mesmo tempo em que negligencia a mundialização constituinte do capitalismo, a qual devemos reinserir entre as rachaduras de sua análise.

\footnotetext{
${ }^{59}$ Permanecemos então com a primeira formulação proposta por Foucault na primeira aula do curso de 1976, Cf. Michel Foucault, "Il faut défendre la société”, op.cit. p. 16 (leçon du 7 janvier 1976). [Michel Foucault, Em defesa da sociedade, 2010, p. 15 (Aula de 7 de janeiro de 1976) - N.T.].

${ }^{60}$ Ibid., p. 41-42 (leçon du 21 janvier 1976). [Michel Foucault, Em defesa da sociedade, 2010, p. 41 (Aula de 21 de janeiro de 1976) - N.T.].
} 
No final da Guerra dos Trinta Anos, em meados do século XVII, explica Foucault, "abre-se uma nova perspectiva histórica, a perspectiva da governamentalidade indefinida, a perspectiva de permanência dos Estados", que demandou que "aceitemos a violência como a forma mais pura da razão e da razão de Estado ${ }^{61 ،}$. Fruto da institucionalização das máquinas de guerra do período feudal, o sistema diplomático-militar constitui o "primeiro conjunto tecnológico" da nova arte de governar, cujo objetivo é o poder e a riqueza dos Estados. Ele é garantia de um equilíbrio de forças que assegura o empoderamento dos Estados. O segundo [74] "conjunto tecnológico", com o mesmo objetivo, é composto pela "polícia" e seu governo da sociedade e da população.

Mas talvez devamos retornar aqui à análise essencial de Carl Schmitt quando este recorda que uma das condições, e não das menos importantes, da instituição do Jus publicum europeu é a divisão do espaço continental, onde se estabeleceu uma "balança de forças" para limitar os poderes dos Estados, e as "terras livres" do Novo Mundo, onde os mesmos Estados podem se colocar em uma competição e uma concorrência sem limites. Se, no continente e na perspectiva de um certo equilíbrio entre estados, a guerra é, de facto, uma continuação da política por outros meios (e a teoria de Clausewitz é, para Foucault, uma sistematização, dois séculos mais tarde, desse equilíbrio de poder entre Estados), no resto do mundo, onde a guerra nunca deixou de ser conquista, saque, violência ilimitada contra homens, bens, terras, a Fórmula de Clausewitz é já e desde sempre revertida na fórmula brutal da "guerra de raças" alimentada pela guerra extra-europeia dos estados esculpindo seus impérios coloniais.

O alcance e o significado do mercantilismo também são parciais na metodologia limitada à Europa utilizada por Foucault, o que o obriga a articular um poder internamente ilimitado sobre a população (o estado policial) e um poder externamente limitado por uma razão de Estado autolimitante em seus próprios objetivos, tendo em vista o "equilíbrio europeu" das nações ${ }^{62}$. O contraste não poderia ser maior em relação ao trabalho clássico de Eric Williams sobre a relação entre o escravagismo e capitalismo, que coloca a equação mercantilismo =

\footnotetext{
${ }^{61}$ Michel Foucault, Sécurité, territoire, population, op. cit., p. 272-273 (leçon du 15 mars 1978). [Michel Foucault, Segurança, território e população, op.cit., p. 356 - N.T.].

62 Cf. Michel Foucault, Naissance de la biopolitique. Cours au Collège de France (1978-1979), Paris, Gallimard/Seuil, 2004, p. 6-8 (leçon du 10 janvier 1979). [Michel Foucault, Nascimento da biopolítica. Curso dado no Collège de France (1978-1979), São Paulo, Martins Fontes, 2008, p. 6-10 (Aula de 10 de janeiro de 1979 - N.T.]. Sobre este "equilíbrio europeu" que serve de objeto do tratado de Vestfália concluído em 1648, ver Michel Foucault, Sécurité, Territoire, Population, op. cit., p. 304-314 (leçon du 22 mars 1978). [Michel Foucault, Segurança, território e população, op.cit., p. 399 - N.T.].
} 
escravidão ("a essência do mercantilismo é a escravidão ${ }^{63 ،}$ ), [75] abrindo toda uma outra perspectiva, muito mais distante do equilíbrio da física diplomático-militar dos Estados, da "fase" que precedeu e estimulou a Revolução Industrial. Que o poder e riqueza dos estados, provenientes em grande parte da exploração das colônias e do comércio de escravizados ("“a principal contribuição externa para o crescimento econômico da Europa ${ }^{64 ،}$ ) é uma evidência da qual encontraremos ecos até em John Stuart Mill, no coração da sucessão liberal ao mercantilismo e à escravidão, quando este afirma em seu Tratado de Economia Política (1848) que “o comércio com as Índias Ocidentais Britânicas não se configura como comércio exterior, mas comércio [tráfico] entre as cidades e o campo" ${ }^{65}$. Com a relativa adaptação do trabalho forçado nas colônias ao "trabalho assalariado livre" na metrópole ${ }^{66}$, que também faz a disciplinarização dos pobres passar pela a escravidão dos negros, é o modo capitalista de produção da nova divisão internacional do trabalho que confirma que, de qualquer lado que abordemos a questão do capitalismo, é impossível excluir a dimensão geopolítica extraeuropeia. Pela simples razão de que esta se faz um ao descolamento da Europa e que lhe coube iniciar o ciclo de produção-consumo de massa, desenvolvendo empresas comerciais militares, incluindo o sucesso que baseava-se, em última análise (in fine), no estabelecimento de uma economia da disciplina, da organização serial (seriatim) de trabalho, do tempo e do espaço em larga escala, o que transformaria plantações de cana de açúcar em laboratórios capitalístico para o regime fabril. Verifica-se, assim, que se o regime colonial é esse "Deus estrangeiro" que, segundo [76] Marx jogou fora os "velhos ídolos da Europa", ele só pôde fazê-lo proclamando e abrindo à força o "caminho do lucro (Plus-macherei) como o único e último objetivo da humanidade" 67 .

${ }^{63}$ Esta é a fórmula de Eric Williams (em Capitalismo e Escravidão, 1944) [Eric Williams, Capitalismo e escravidão, São Paulo, Companhia das letras, 2012 - N.T.] citado por Fernand Braudel, Civilisation matérielle, économie et capitalisme, xv-xviii siècle, t. 3, Le temps du Monde, Paris, Armand Colin, 1979, p. 337. [Civilização material, economia e capitalismo - vol. 3: séculos XV-XVIII - O tempo do mundo, São Paulo, Martins Fontes WMF, 2009 - N.T.].

${ }^{64}$ Sidney W. Mintz, Sweetness and Power. The Place of Sugar in Modem History, New York et Londres, Penguin, 1985, p. 55.

${ }^{65}$ John Stuart Mill. Principless of Political Economy (1848), New York, D. Appleton, 1876, p. 685-686 (cité par Sidney W. Mintz, op. cit., p. 42).

${ }^{66}$ Mas devemos ter o cuidado de não esquecer que "na Nova Espanha, a partir do século XVII, o trabalho 'livre' para os assalariados apareceu" no seio mesmo da sucessão e da invasão das servidões características do Novo Mundo (cf. Femand Braudel, op. cit., p. 338-339).

${ }^{67}$ Marx, Le Capital, livre I, section V] II, chap. XXXI, op. cit., p. 1216 (et note). [Karl Marx, 2017, p. 824 - N.T.] 


\section{5/ Genealogia colonial das disciplinas da biopolítica}

As críticas formuladas por autores pós-coloniais, sem que seja necessário concordar com elas na íntegra, podem ser úteis para se problematizar a abordagem foucaultiana e suas deficiências. Para retomar, os dois pólos de desenvolvimento do exercício do poder sobre os homens desde o rompimento com os rituais feudais do poder soberano, o poder disciplinar centrado no corpo como uma máquina integrada aos "sistemas de controle eficazes e econômicos" e o biopoder, "que se transformou um pouco mais tarde" em uma biopolítica populacional $^{68}$, datam, respectivamente, da metade ou do final do século XVII e do século XVIII. Todavia, nos parece que seu desenvolvimento diferenciado constitui apenas uma segunda etapa na construção dos dispositivos de poder do capitalismo, que se torna mais significativa se for pensada tanto em relação de ruptura quanto de continuidade com os dois primeiros séculos de "acumulação primitiva".

Encontramos alguns traços dessa relação de ruptura e continuidade no curso de 19731974, O poder psiquiátrico, em que Foucault amplia o espaço de constituição dos dispositivos de saber e de poder para a economia-mundo traçando um paralelo entre a metrópole e as colônias. Nestas páginas, a "colonização interna" de vagabundos, nômades, delinquentes, prostitutas, é espelhada com a "colonização externa" dos povos colonizados sobre os quais se exerce e experimenta os mesmos dispositivos disciplinares que na Europa. "Devemos ver um pouco mais detalhadamente como os esquemas disciplinares foram simultaneamente aplicados e refinados em populações coloniais. Parece que esta disciplinarização é feita primeiro de uma forma um pouco discreta, marginal e, curiosamente, em contraponto à escravidão" $"$.

A economia-mundo articula seus dispositivos de poder com o saber e a um novo conceito de "verdade" adequado para funções de controle e governo das populações, de acordo com um "procedimento de controle contínuo" ("é uma tomada do corpo, e não de um produto; é uma tomada do tempo em sua totalidade, e não de um serviço") para o qual o sistema disciplinar do exército fornece o modelo ${ }^{70}$. É este modelo que se estenderá a toda a superfície

\footnotetext{
${ }^{68}$ Michel Foucault, La Volonté de savoir, op. cit., p. 182-183 [Michel Foucault, A vontade de saber, 2017, p. 149150 - N.T.].

${ }^{69}$ Michel Foucault, Le Pouvoir psychiatrique. Cours au Collège de France (1973-1974), Paris, Gallimard/Seuil, 1973, p. 70 (leçon du 28 novembre 1973) [Michel Foucault, O Poder Psiquiátrico. Curso dado no Collège de France (1973-1974), São Paulo, Martins Fontes, 2006, p. 86 (Aula de 28 de novembro de 1973) - N.T.].

70 Ibid., p. 48-49. [Michel Foucault, O Poder psiquiátrico, op.cit., p. 58-59 (Aula de 23 de janeiro de 1974) N.T.]. Esta será uma das principais teses de Vigiar e Punir. Foucault dará o crédito a Marx em entrevista publicada
} 
do globo. Sua extensão planetária se confunde com um "duplo movimento de colonização" que se reforça mutuamente: "a colonização em profundidade que parasitava até os gestos, os corpos, o pensamento dos indivíduos, e depois a colonização na escala de territórios e superfícies"71. Estamos aqui - um aqui que nos transporta para estes microcosmos disciplinares quase panópticos de produção e de vigilância que são os estabelecimentos jesuítas no Paraguai ${ }^{72}$ - no coração da "investigação generalizada de toda a superfície da terra", produzindo um saber sobre o comportamento das pessoas, a maneira como elas vivem, pensam, fazem amor. "Ou seja, em todos os momentos e em qualquer lugar do mundo, e sobre qualquer coisa,[78] pode-se e devese colocar a questão acerca da verdade. Existe verdade em toda parte a verdade nos espera em todos os lugares"73. De acordo com as modalidades que Locke nos permitiu descobrir, essa produção universal de verdade requer formas de pensamento e "tecnologias" que permitam acessá-la, produzindo o sujeito de sua enunciação e de sua recepção. É de fato necessário "um sujeito universal dessa verdade universal, mas este será um sujeito abstrato porque, concretamente, o sujeito universal capaz de entender essa verdade será raro, terá que ser um sujeito qualificado por uma série de processos que serão precisamente os processos de pedagogia e seleção ${ }^{74 \%}$. Será um sujeito educado pelo saber da acumulação de capital, um sujeito equipado para o poder sobre o acúmulo de homens e a colonização sistemática deles. É definitivamente uma pena que o experimento "disciplinar" liderado pelos jesuítas nas comunidades Guaranis no Paraguai não tenha encontrado consequência no trabalho de Foucault, porque a abertura à biogeopolítica mundial do capitalismo se fechou rapidamente.

Conceber a articulação dos conceitos de biopoder e de poder disciplinar em uma genealogia que compreenderia a acumulação primitiva como sua origem permitiria entender de que modo eles continuam a guerra por outros meios, em particular no que diz respeito à "guerra

\footnotetext{
na revista Hérodote (1976): “tudo o que Marx escreveu sobre o exército e seu papel no desenvolvimento do poder político [...] são coisas muito importantes que foram praticamente deixadas de lado para o benefício dos comentários incessantes sobre a mais-valia” ("Questions à Michel Foucault sur la géographie », Dits et Écrits, op. cit., t. III, $\mathrm{n}^{\circ}$ 169, p.39). [Michel Foucault, "Sobre a geografia”, em Microfísica do poder, Rio de Janeiro/São Paulo, Paz e Terra, 2017, p. 260 - N.T.].

71 Ibid., p. 246 (leçon du 23 janvier 1974) [Michel Foucault, O Poder psiquiátrico, op. cit., p. 315-316 (Aula de 23 de janeiro de 1974) - N.T.].

${ }^{72}$ Foucault já se referiu a eles em uma conferência em 1967 no Cercle d'Etudes architectes, cf. Michel Foucault, «Des espaces autres » [1984], Dits et Écrits, op. cit., t. II, n 360, pág. 1580. [Michel Foucault, "Outros espaços” [1984], em Ditos e escritos, III. Estética, Rio de Janeiro, Editora Forense, 2009, p. 411 - N.T.].

${ }^{73}$ Michel Foucault, Le Pouvoir psychiatrique, op. cit., p. 246. [Michel Foucault, O Poder psiquiátrico, op. cit., p. 316 - N.T.].

${ }^{74}$ Ibid., p. 247. [Ibid., p. 316 - N.T.].
} 
contra as mulheres". A definição de biopoder como dispositivo de produção e de controle de processos "de natalidade, de fecundidade, de mortalidade, de longevidade" e como gestão da "reprodução" da população pelo Estado ${ }^{75}$ ganharia muito se pensada como resultado de políticas de expropriação e apropriação dos "corpos" das mulheres, que exercem seu poder sobre a "reprodução" da força de trabalho e toda uma biopolítica do corpo $^{76}$. Verificamos que o poder de "regularização" de uma [79] biopolítica caracterizada por governar a vida das populações depende de "todo um conjunto disciplinar que pulula sob os mecanismos de segurança para lhes fazer funcionar"77. Isto acarretaria também em um alcance completamente diferente na análise do liberalismo econômico, em todos os aspectos ligado às técnicas disciplinares, na medida em que a disciplinarização da vida apareceria como a matriz biopolítica do controle econômico-político da produção. Parece-nos, em todo caso, necessário inclinar nesse sentido a fórmula de Bentham-Foucault: “o panóptico é a própria fórmula de um governo liberal ${ }^{78 ،}$.

\section{6/ O racismo e a guerra das raças}

Mas a questão mais espinhosa diz respeito à genealogia foucaultiana do "racismo de Estado". Na última aula de "Em defesa da sociedade", Michel Foucault nos incita a entender a conceito de biopoder como uma "relação biológica" e "não mais militar, bélica ou política". Essa afirmação mereceria ser problematizada à luz dos processos de redução de mulheres e colonizados a uma existência biológica que não poderia ser realizada e continuada senão pela guerra das raças e pela guerra contra as mulheres: de fato, se a acumulação primitiva mostra a estrita implicação entre o biopoder e a guerra, e a impossibilidade de distingui-los, então são os dispositivos "foucaultianos" que constituem a continuação das guerras de acumulação primitiva por outros meios. Embora reconhecendo que o racismo se desenvolveu "primo com a

\footnotetext{
${ }^{75}$ Michel Foucault, «Il faut défendre la société», op. cit., p. 216-217 (leçon du 17 mars 1976). [Michel Foucault, Em defesa da sociedade, p. 204-205 (Aula de 17 de março de 1976) - N.T.]

${ }^{76}$ Em suas intervenções políticas, Foucault não deixa de incluir essa "função reprodutiva da força de trabalho" em uma "política do corpo" que tem o efeito imediato de politizar a sexualidade. (cf. «Sexualité et politique» [1974] Dits et Ecrits, op. cit., II, n ${ }^{\circ} 138$, p. 1405).

${ }^{77}$ Michel Foucault, Sécurité, territoire, population, op. cit., p. 10. [Michel Foucault, Segurança, território e população, op.cit., p. 11 - N.T.].

${ }^{78}$ Michel Foucault, Naissance de la biopolitique, op. cit., p. 69 (leçon du 24 janvier 1979) [Michel Foucault, Nascimento da biopolítica, op.cit., p. 91 - N.T.].
} 
colonização, ou seja, com o genocídio colonizador ${ }^{79 ",}$, Foucault continua fortemente centrado na Europa. Sua [80] problematização da guerra como emblema das relações sociais e sua genealogia do racismo de Estado encontram-se consideravelmente enfraquecidas. Para ele, “o que inscreve o racismo no mecanismo de Estado é o surgimento do biopoder", o que ele faz aqui remontar sintomaticamente ao século $\mathrm{XIX}^{80}$.

Se o biopoder é um poder que "gerencia a vida", que a "organiza, protege, garante, cultiva biologicamente ${ }^{81}$ ", se o biopoder, ao contrário do poder soberano ("fazer morrer e deixar viver"), é exercido através de um novo direito ("fazer viver e deixar morrer"), como garantir a função específica de guerra que é o direito de matar? Através do racismo, responde Foucault! “O racismo permitirá estabelecer, entre a minha própria vida e a morte do outro, uma relação que não é militar ou de confronto, mas uma relação biológica" permitindo simultaneamente uma "extrapolação biológica do tema do inimigo político" e a inscrição "da função de morte na economia do biopoder", que realiza um "corte" no continuum biológico e assim recupera "o antigo direito soberano de matar" ${ }^{\prime 2}$. Nestas páginas, a ascensão do racismo no final de século XIX parece não ter qualquer conexão com a evolução da economia-mundo e com o imperialismo, que leva ao seu auge a conquista colonial e se precipita para a Primeira Guerra Mundial. Aqui, novamente, a estrutura eurocêntrica da análise limita a explicação (que regressa para a morte própria do poder soberano, conduzindo Foucault em direção a um curioso efeito de quiasma ${ }^{83}$ ), desde as primeiras[81] manifestações das políticas do "racismo de Estado", não concernentes à Europa, mas às colônias e à escravidão.

A origem da escravidão certamente não deve ser procurada nas políticas da "raça". Ela é, principalmente, um problema econômico devido por um lado às políticas de extermínio e, por outro, à "fraqueza" de índios e brancos "contratados", incapazes de fornecer o trabalho forçado nas minas e nas plantações do Novo Mundo. “A escravidão não nasceu do racismo. $\mathrm{O}$

\footnotetext{
${ }^{79}$ Michel Foucault, «Il faut défendre la société», op. cit., p. 229 (leçon du 17 mars 1976). [Michel Foucault, Em defesa da sociedade, p. 216 (Aula de 17 de março de 1976) - N.T.].

${ }^{80}$ Ibid., p. 226-227. [Michel Foucault, Em defesa da sociedade, p. 214 (Aula de 17 de março de 1976) - N.T.].

${ }^{81}$ Ibid., p. 232. [Michel Foucault, Em defesa da sociedade, p. 219 (Aula de 17 de março de 1976) - N.T.].

${ }^{82}$ Ibid., p. 227-229. [Michel Foucault, Em defesa da sociedade, p. 214-217 (Aula de 17 de março de 1976) - N.T.].

${ }^{83}$ Lemos, portanto: "Se o poder de normalização quer exercer o velho direito soberano de matar, ele tem de passar pelo racismo. E se, inversamente, um poder de soberania, quer dizer, um poder que tem um direito de vida e de morte, quer funcionar com os instrumentos, com os mecanismos, com a tecnologia da normalização, é preciso que ele também passe pelo racismo." (ibid., p. 228). [Michel Foucault, Em defesa da sociedade, p. 216 (Aula de 17 de março de 1976) - N.T.].
} 
racismo é mais a consequência da escravidão" ${ }^{84}$. Mas a manutenção e a estabilização de políticas escravagistas exigem o estabelecimento de políticas raciais. Muito cedo, nas colônias espanholas, durante os anos 1540, “a 'raça' se tornou um fator essencial na transmissão de propriedade e uma hierarquia racial foi instituída para diferenciar os indígenas, os mestiços e os mulatos entre si e a população branca ${ }^{85}$ ". O Estado francês, por sua vez, dará uma estrutura "legal” às guerras raciais com o Code noir (1685) e o Native Code (1881).

O racismo de Estado, portanto, não nasce no final do século XIX na Europa como consequência da implantação do biopoder em uma "sociedade de normalização" e através da adaptação de temas científicos do evolucionismo, ele é constitutivo da montagem de funções estatais que projetaram um biopoder disciplinar sobre a economia-mundo. E se é verdade que o racismo de Estado do final do século XIX é indubitavelmente diferente, a novidade está na importação e na transformação de políticas raciais que são inseparáveis de técnicas de "governo" das populações colonizadas há séculos. Ao longo de todo século XIX, e especialmente na França, foram assim importadas das colônias técnicas de guerra civil para aniquilar insurreições de trabalhadores; e no que concerne às guerras do século XX, para seguir Paul Virilio, a guerra total "já estava mais[82] perto da empresa colonial do que da guerra tradicional na Europa ${ }^{86 ، .}$.

O Nazismo, ponto culminante e a solução final do racismo de Estado, no qual Foucault percebe a absoluta coincidência de um Estado disciplinar total, de um biopoder generalizado e a difusão do "velho poder soberano de matar" em todo o corpo social, não é apenas a resultante suicida das biodinâmicas europeias precipitadas na guerra como "fase última e decisiva de todos os processos políticos" ${ }^{\$ 7}$. O poeta Aimé Césaire compreende isso, de outro lugar, como o fruto primeiro da colonização que funcionava "para descivilizar o colonizador" produzindo a selvageria lenta, mas segura, da Europa. O motivo de não perdoarmos Hitler "não é o crime em si, o crime contra a humanidade, não é a humilhação do ser humano em si mesma, é o crime contra o homem branco, é a humilhação do homem branco, e ter aplicado à Europa processos

\footnotetext{
${ }^{84}$ Eric Williams, Capitalisme et esclavage, Paris, Présence africaine, 1968, p. 19. [Eric Williams, Capitalismo e escravidão, São Paulo, Companhia das Letras, 2012, p. 34 - N.T.].

85 Silvia Federici, op. cit., p. 222. [Silvia Federici, 2017, p. 218 - N.T.].

${ }^{86}$ Paul Virilio, L'Insécurité du territoire (1976), Paris, Galilée, 1993, p. 136.

${ }^{87}$ Michel Foucault, «Il faut défendre la société», op. cit., p. 231-232. [Michel Foucault, Em defesa da sociedade, p. 218-219 (Aula de 17 de março de 1976) - N.T.].
} 
colonialistas os quais até agora pertenciam apenas aos árabes da Argélia, aos coolies da Índia e aos negros da África" ${ }^{\natural 8}$.

\section{7/ Guerra da/na economia-mundo}

Portanto, não surpreende que os autores associados a pesquisas sobre a economiamundo complementem e enriqueçam a análise das transformações da guerra e das formas de colocá-la em relação direta com o capitalismo nascente e com as colônias. É, com efeito, a “acumulação primitiva" que fornece o crisol de todas as funções que a guerra desenvolverá depois: estabelecimento dos dispositivos disciplinares de poder, racionalização e aceleração da produção, campo de testes e desenvolvimento [83] de novas tecnologias, gestão biopolítica da força produtiva em si. Mas, acima de tudo, a guerra desempenha um papel primordial na "governamentalidade" da multiplicidade dos modos de produção, das formações sociais e dos dispositivos de poder que coexistem no capitalismo em escala mundial. Ela não se limita a ser a continuação no plano estratégico da política (estrangeira) dos Estados. Ela ajuda a produzir e a manter juntos os diferenciais que definem as divisões de trabalho, de gênero e de raça sem as quais o capitalismo não poderia se alimentar das desigualdades que libera.

Fernand Braudel ressalta que a guerra "renovada pela técnica, criadora da modernidade", trabalha na implementação acelerada do capitalismo: "A partir do século XVI, houve uma guerra de pico que mobilizou furiosamente os créditos, a inteligência, a engenhosidade das técnicas, a ponto de mudar, dizia-se, de um ano para o outro ${ }^{89}$. "Para Immanuel Wallerstein, fazendo referência ao mesmo período, a guerra é tanto uma fonte de emprego para os pobres quanto uma força produtiva de primeira grandeza que estimula o crédito. "O aumento dos gastos militares estimulou frequentemente a produção em outras áreas, de modo que o volume de produtos excedentes aumentava em tempos de guerra". A logística militar não solicitava apenas o comércio e a produção, "era um sistema de criação de crédito. $\mathrm{Na}$ verdade, os príncipes não eram os únicos a pedir empréstimos a banqueiros, empreiteiros militares também pediam"90.

\footnotetext{
88 Aimé Césaire, Discours sur le colonialisme (1950), Paris, Présence africaine, 2011, p. 14. [Aimé Césaire, Discurso sobre o colonialismo, Florianópolis, Letras contemporâneas, 2010, p. 18 - N.T.].

${ }^{89}$ Fernand Braudel, op. cit., p. 44.

${ }^{90}$ Immanuel Wallerstein, Capitalisme et économie-monde (1450-1640), Paris, Flammarion, 1980, p. 131.
} 
Lembrando que "a guerra no Brasil não pode ser a guerra de Flandres”, Braudel nos dá mais uma indicação importante quanto ao fato de que a acumulação primitiva exige mudanças profundas na maneira de se conduzir a guerra, inclinando-a para a guerrilha, algo cuja emergência Carl Schmitt data muito mais tarde, de acordo com um calendário europeu que o faz favorecer as formas [84] de resistência que as guerras napoleônicas suscitaram, notadamente na Espanha.

A guerra, "filha e mãe do progresso", que acompanha o Estado-nação como sua sombra projetada e contribui para o desenvolvimento da "civilização" do capitalismo, existe apenas na cena da economia-mundo. Na periferia, nas colônias, praticamos uma guerra de pobres contra os bárbaros, a única que é adequada aos seus "meios". Para consternação dos soldados profissionais enviados às “Américas”, é impossível travar uma guerra na África, no Brasil ou no Canadá de acordo com as regras europeias de uso (as "leis da guerra"). A guerra de mato (ou guerra da floresta) ou guerra voadora, travada pelas tropas levantadas no local (os soldados da terra) no Nordeste brasileiro, é, portanto, menos uma inovação tática do que uma espécie de revolução estratégica na arte "ocidental" da guerra, que as guerras coloniais e o racismo de Estado que os acompanham nunca cessarão de reproduzir e expandir.

\section{8/ Acumulação primitiva em debate}

A acumulação primitiva constitui a verdadeira "matriz" do capitalismo, desde que se possa fazer modificações profundas no quadro desenhado por Marx em $O$ Capital. Na análise marxiana da transição, podemos apontar para dois "limites" que afetarão toda a análise do capitalismo.

É, antes de tudo, a redução da multiplicidade das guerras dos sexos, das raças, das subjetividades, das civilizações, etc., que estruturam a divisão social do trabalho à relação exclusiva capital/trabalho. De nossa parte, queríamos mostrar que a acumulação primitiva é, desde o início, uma criação/destruição continuada portadora do funcionamento real do mercado mundial, já que produz e reproduz os diferenciais entre uma multiplicidade de modos de produção e exploração do trabalho, de formações sociais, de [85] dispositivos de poder e dominação irredutíveis exclusivamente ao "modo de produção".

Em segundo lugar, há essa concepção progressista, evolutiva e linear do tempo e da história que tende a "enquadrar" toda a análise da acumulação primitiva e que interdita 
amplamente o desenvolvimento político das análises históricas apresentadas por Marx ${ }^{91}$. O que Marx chama de "acumulação primitiva" não ocorreu de uma vez por todas. Repete-se, segundo Deleuze e Guattari, a cada nova montagem de um aparelho de captura em relação a todas as possíveis figuras do capitalismo. Com o capitalismo financeiro, a contemporaneidade da "acumulação primitiva", da conquista e da expropriação, agindo sob a capa do "comércio" com os processos produtivos dos mais modernos, se impõe por si mesma. [86]

Esta definição de acumulação primitiva como um processo essencialmente ligado ao desenvolvimento do capitalismo (e não à sua pré-história) não é novidade. Ela é imposta no início do século 20, com a nova onda de colonização liderada pelo capital financeiro, que sugere que o imperialismo não é uma opção dentre outras para o capitalismo. Rosa Luxemburgo é, sem dúvida, a primeira a conceber a acumulação primitiva como um fenômeno menos "histórico" do que contemporâneo do capitalismo, que prossegue no século XX em sua forma imperialista. Se a acumulação não para de se produzir e se reproduzir, ela não diz respeito, todavia, senão ao "fora" do capitalismo industrial e se exerce na periferia, atormentado pela violência da anexação de novos territórios ("tomadas de terras": landnahme ${ }^{92}$ ), enquanto o centro está "pacificado".

A acumulação de capital, portanto, tem um duplo aspecto. "Um diz respeito à produção de mais-valia - na fábrica, na mina, na exploração agrícola - e à circulação de mercadorias no mercado. Considerada deste ponto de vista, a acumulação é um processo permanente, cuja fase

\footnotetext{
${ }^{91}$ Nos últimos anos de sua vida, Marx empreendeu uma afinação em sua teoria da acumulação primitiva. A oportunidade é dada por um artigo do sociólogo "populista" russo N. Mikhailovski, que criticou sua (alegada?) filosofia de uma fatalidade universal do desenvolvimento do capitalismo. Em sua resposta, em 1877, Marx lembra que ele se engajou principalmente em uma análise histórica da gênese do capitalismo na Europa Ocidental e que cabe unicamente a Mikhailovski tê-la transfomado em "uma teoria histórico-filosófica da marcha geral, fatalmente imposta a todos os povos, quaisquer que sejam as circunstâncias onde estão localizados" (Karl Marx, « La commune rurale et les perspectives révolutionnaires en Russie », in Euvres, t. II, Paris, Gallimard, « Bibliothèque de la Pléiade », 1968, p. 1555) [Karl Marx, "À redação de Otietchestvieniie Zapiski”, em Dilemas do Socialismo: a controvérsia entre Marx, Engels e os populistas russos, Rio de Janeiro, Paz e Terra, 1982, p. 167 - N.T.].

Em 1881, solicitada por uma carta de Vera Zassoulitch para falar sobre a "questão agrária" e a "comunidade rural" na Rússia, Marx aproveita a oportunidade para esclarecer seu ponto de vista sobre a transição para o socialismo. A Rússia não está destinada a seguir as "forcas caudinas da sequência europeia: formação social pré-capitalista, acumulação primitiva, capitalismo, socialismo. Graças à propriedade comum do solo, a "comuma rural" russa "pode se tornar um ponto de partida direto do sistema econômico ao qual tende à sociedade moderna; ela pode fazer o novo sem antes cometer suicídio; ela pode colher os frutos com os quais a produção capitalista enriqueceu a sociedade sem passar pelo regime socialista" (p. 1565). A questão da transição não é um problema teórico: "Para salvar a comuna russa, deve haver uma Revolução Russa" (p. 1573). Em virtude de seu atraso mesmo, a comuna rural, no âmbito da revolução, "em breve se desenvolverá como um elemento regenerador da sociedade russa e como um elemento de superioridade sobre os países escravizados pelo regime capitalista" (p. 1573). Essas passagens são extratos dos rascunhos da carta de resposta que Marx enviou a V. Zassoulitch. [Karl Marx, 2017, p. 849-850].

${ }^{92}$ Rosa Luxemburgo foi a primeira a usar esse termo, mesmo que Carl Schmitt nunca a retome.
} 
mais importante é uma transação entre o capitalista e o assalariado [...] sob o signo da paz, da propriedade privada e da igualdade". Esta primeira ponta da acumulação ocorre no "Norte", enquanto a segunda ponta, sua parte indizível, diz respeito às relações do capital com o "Sul” e seus modos de produção não-capitalistas. "Aqui os métodos empregados são a política colonial; os sistemas internacionais de empréstimos, a política de esferas de interesse, a guerra. A violência, a fraude, a opressão, a pilhagem se desenrolam abertamente, sem máscara, e é difícil reconhecer as leis rigorosas do processo econômico no emaranhado de violências e brutalidades policiais" $" 93$. [87]

Se os dois lados da acumulação constituem "um mesmo fenômeno orgânico", referemse a um "dentro" e a um "fora" do Capital propriamente dito, em um tempo em que o ambiente não capitalista "representa [geograficamente] ainda hoje a maior parte do mundo", e em que as economias não capitalistas persistem em grandes zonas partes da própria Europa.

A globalização contemporânea apagou esse "fora" espacial a conquistar, aquilo que Rosa Luxemburgo disse ser a condição de sobrevivência do capitalismo. A violência, a fraude, a opressão, a guerra são igualmente exercidas contra os assalariados do Norte "rico", que até ali haviam se beneficiado, de uma maneira ou de outra, da pilhagem do "Terceiro Mundo". O capitalismo financeiro contemporâneo trouxe à ordem do dia a crítica da acumulação primitiva iniciada por Rosa Luxemburgo. A mais recente a de David Harvey, que gostaria, com seu conceito de "acumulação por espoliação", de se destacar da noção da redução da acumulação primitiva a um "estágio original" a ser superado (Marx) ou da sua projeção na realidade “exterior" ao centro do capitalismo (Rosa Luxemburgo). Harvey continua dentro do escopo da análise marxista, uma vez que aceita a função "progressista" do capital, identificado ao capital industrial e à acumulação primitiva que lhe abrem o caminho. A "acumulação por espoliação" operada pelo capital financeiro e baseada na desapropriação dos 'detentores de recursos' é, pelo contrário, denunciada à medida em que ataca o desenvolvimento industrial.

“Apesar da violência de classe abjeta", a acumulação primitiva ainda assim representa "a liberação de energias criativas, a abertura da sociedade a fortes correntes de inovação tecnológica e organizacional, substituindo um mundo dependente da superstição e da ignorância por um mundo fundado no conhecimento e capaz de libertar o homem da escassez

93 Rosa Luxemburg, Euvres, t. IV, L'Accumulation du capital, Paris, Maspero, 1969, p. 116-117. [Rosa Luxemburg, A acumulação do capital, São Paulo, Nova Cultural, 1988, vol. 2, pp. 86-7 - N.T.]. 
e das necessidades materiais ${ }^{94}$." Vamos pensar aqui em uma famosa passagem do Manifesto Comunista, restaurada ao gosto do dia pelos "aceleracionistas".

Tanto que esses "aspectos positivos" da acumulação primitiva se verificariam ainda no mundo contemporâneo, lá onde ela ainda está diretamente em curso. Então, na década de 1980, a industrialização de um país como a Indonésia teria aberto “oportunidades" para a população, que a desindustrialização causada pela crise 1997-1998, em grande parte, destruiu. Quem “causou mais danos às esperanças e aspirações de longo prazo deste país: a acumulação primitiva que se abre para industrialização ou desindustrialização financeira?, pergunta Harvey. Se ele reconhece a correlação entre eles, o fato é que a acumulação primitiva como portadora de uma "mudança mais positiva" é uma coisa, enquanto a "acumulação por espoliação que atrapalha e destrói o caminho já aberto é outra"95. O que Harvey chama de "desindustrialização" é na realidade uma reconfiguração completa da divisão internacional do trabalho, na qual o capital financeiro foi a cabeça estratégica e não o "parasita". O dito "capital fíctício" lidera com sucesso a configuração de um novo regime de acumulação em que a desapropriação dos "detentores de recursos" e a exploração do assalariado, a guerra, a violência, a pilhagem e a mais real das economias coexistem em um nível inigualável.

A verdadeira máquina de guerra do capital é a financeirização, o capital "industrial” é apenas um componente, completamente reestruturado e subordinado aos requisitos do capital "fictício". O capitalismo contemporâneo inverte a formulação de Marx segundo a qual a renda faz parte do lucro, pois é sobretudo o último que deriva da renda. É por isso que a análise marxista do capitalismo contemporâneo desenvolvida por Harvey leva a propostas políticas particularmente fracas. Mantendo a distinção clássica entre o capital industrial e o capital financeiro, Harvey foi forçado a inventar uma dialética política para unir o que ele mesmo separou, as "lutas no campo da reprodução estendida" 96 , isto é, as lutas clássicas do movimento operário e as lutas contra a acumulação por espoliação realizadas pelos movimentos “outromundistas". Evitar a questão política imposta pela hegemonia do capital financeiro, a saber, a impossibilidade de distinguir acumulação por exploração e "acumulação por espoliação", é ignorar a guerra da/na economia.

\footnotetext{
${ }^{94}$ David Harvey, Le Nouvel Impérialisme, Paris, Les Prairies ordinaires, 2010, p. 192. [David Harvey, O novo imperialismo, São Paulo: Edições Loyola, 2005, p. 134 - N.T.].

${ }^{95}$ Ibid., p. 193. [Ibid., p. 135 - N.T.].

${ }^{96}$ Ibid., p. 205. [Ibid., p. $146-$ N.T.].
} 
Não marxista, e, portanto, relutante ao progressismo do capital, Hannah Arendt apresenta sob a forma de um balanço do imperialismo, desde as guerras coloniais do século 19 até as guerras totais da primeira metade do século 20, o que a hegemonia do capital financeiro revelou:

As depressões das décadas de 1860 e 1870, que abriram a era do imperialismo, desempenharam um papel decisivo ao forçar a burguesia a perceber pela primeira vez que o pecado original da pilhagem pura e simples que, séculos antes, permitiu "a acumulação original do capital "(Marx) e iniciou toda a acumulação por vir, ia ter que se repetir se não quiséssemos ver morrer repentinamente o motor da acumulação. Diante deste perigo, que ameaçaria não apenas a burguesia, mas também toda a nação, de uma queda catastrófica da produção, produtores capitalistas entenderam que as formas e as leis de seu sistema de produção 'tinham sido calculados desde a origem à escala da Terra inteira' (Rosa Luxemburgo)" 97.

${ }^{97}$ Hannah Arendt, Les Origines du totalitarisme, Paris, Gallimard, « Quarto », 2002, p. 384. [Hannah Arendt, Origens do totalitarismo: Anti-semitismo, Imperialismo, Totalitarismo, São Paulo, Companhia das Letras, 2004, p. 178. - N.T.]. 